\title{
Pathogenicity and aggressiveness of Colletotrichum gloeosporioides isolates in ornamental pepper ${ }^{1}$
}

\author{
Neilton Antonio Fiusa Araújo ${ }^{2}$, Joana D'arc Mendes Vieira ${ }^{2}$, \\ Marlene da Rocha Moura², Wagner Rogério Leocádio Soares Pessoa², Beatriz Meireles Barguil ${ }^{2}$
}

\begin{abstract}
Anthracnose, a disease caused by fungi of the Colletotrichum genus, affects many crops, including ornamental plants. This study aimed at evaluating the pathogenicity and aggressiveness of the Colletotrichum gloeosporioides Penz. (Sacc.) isolates $\mathrm{Cg}_{1}$ (papaya), $\mathrm{Cg}_{2}$ (guava) and $\mathrm{Cg}_{3}$ (mango) in the ornamental pepper varieties Stromboli, Etna and Pirâmide, during two different periods (July/August and November/December 2013). The fungi pathogenicity and the severity of plant symptoms were assessed using a grading scale. The three $C$. gloeosporioides isolates were pathogenic to the three ornamental pepper varieties studied, exhibiting different levels of aggressiveness among them. The environmental conditions influenced the isolates aggressiveness, with the most severe symptoms observed in the second assessment period.
\end{abstract}

KEY-WORDS: Capsicum frutescens; phytopathogenic fungi; anthracnose.

\section{INTRODUCTION}

In Brazil, the ornamental plant and flower trade generates around BRL 5.7 billion per year. This supply chain has 8,000 registered producers and creates approximately 215,000 direct jobs, distributed among the production $(39.5 \%)$, distribution $(3.1 \%)$ and retail $(49.7 \%)$ sectors, as well as supporting functions (7.7 \%) (Ibraflor 2016). Flower farming encompasses a wide range of products, such as ornamental plants, fresh or dried flowers, potted plants, fresh and dried foliage, grafted plants, cuttings, seedlings and large trees (Thomaz \& Raquel 2007).

Chili peppers exhibit significant genetic variability and considerable potential for commercialization as potted ornamental plants (Stomel et al. 2006). Any species of chili pepper may be used as ornamental plants, but the most

\section{RESUMO}

Patogenicidade e agressividade de isolados de Colletotrichum gloeosporioides em pimenta ornamental

A antracnose é uma doença causada por fungos do gênero Colletotrichum que afeta inúmeras culturas, inclusive plantas ornamentais. Objetivou-se avaliar a patogenicidade e agressividade de isolados de Colletotrichum gloeosporioides Penz. (Sacc.) $\mathrm{Cg}_{1}$ (mamoeiro), $\mathrm{Cg}_{2}$ (goiabeira) e $\mathrm{Cg}_{3}$ (mangueira), nas variedades de pimentas ornamentais Stromboli, Etna e Pirâmide, em duas épocas do ano (julho/agosto e novembro/dezembro de 2013). Avaliou-se a patogenicidade dos fungos e a severidade dos sintomas nas plantas utilizando-se uma escala de notas. Os três isolados de C. gloeosporioides foram patogênicos às três variedades de pimenta ornamental avaliadas, apresentando níveis diferenciados de agressividade entre as variedades. Houve influência das condições ambientais na agressividade dos isolados, sendo que a maior severidade foi obtida na segunda época de condução do experimento.

PALAVRAS-CHAVE: Capsicum frutescens; fungos fitopatogênicos; antracnose.

recommended ones for potted planting are smaller species such as Capsicum frutescens (L.) and Capsicum annuum (L.), which can be kept indoors (Xavier et al. 2006, Neuhaus et al. 2010). Shape, size and color vary in leaves and fruits, with the latter displaying different levels of pungency. The most commonly observed color is red, but milky yellow, bright yellow, orange, salmon pink, purple and black also occur. Factors that contribute to their success as ornamental plants include easy seed germination, short germination time and heat tolerance. In landscapes, they may be used to create thick and bright colored hedges (Stommel \& Bosland 2006).

Anthracnose, caused by species of the Colletotrichum genus, is a common and highly destructive disease in a number of crops, including ornamental plants. It occurs worldwide and causes significant losses, particularly in tropical and 
subtropical regions (Agrios 2005). Plants can be infected during any stage of development and symptoms emerge after fungi colonization and are characterized by dark, sunken round or oval-shaped lesions on leaves, inflorescences or fruits. Under favorable conditions, conidial masses are formed (Menezes 2006).

The species C. acutatum (Sim.) and C. gloeosporioides Penz. (Sacc.) have been associated with anthracnose in chili peppers, bell peppers and scarlet eggplants, in four Brazilian States (Tozze Júnior et al. 2006). In the Rio Grande do Sul and São Paulo States, Colletotrichum boninense (Moriwaki) has also been reported, causing lesions on fruits and leaves of the bell pepper "Amanda" cultivar (Tozze Júnior et. al 2009). Costa et al. (2006) reported the occurrence of Colletotrichum coccodes (Wallr.) S. Hughes as another causal agent of anthracnose, in nightshades in the country.

Although anthracnose has been studied in several plant species, there is little information on its occurrence, aggressiveness of its isolates or resistance of ornamental plant species. Thus, this study aimed at determining the susceptibility of ornamental pepper varieties to isolates of Colletotrichum gloeosporioides obtained from fruit species.

\section{MATERIAL AND METHODS}

The experiment was conducted in a greenhouse, at the Universidade Estadual do Piauí, in Picos ( $7^{\circ} 2^{\prime}$ S and $41^{\circ} 29^{\prime} \mathrm{W}$ ), where the average annual temperature is $30.2{ }^{\circ} \mathrm{C}$ (Brasil 2013). Assays were conducted during two periods, within the same year: July to August and November to December, 2013.

The experiment was carried out using a $3 \times 3+4$ (control treatments) factorial arrangement, in a completely randomized design, with nine replicates and one plant per plot. The treatments consisted of three Capsicum frutescens varieties inoculated with three Colletotrichum gloeosporioides isolates, in addition to a negative and a positive control. A negative control was used for each variety, in the form of plants sprayed only with sterile distilled water, totaling three negative control treatments. The aji pepper variety (Capsicum baccatum L.) was used as a positive control due to its high susceptibility to the pathogen.

Commercial seeds from the following Capsicum frutescens varieties were obtained for the experiment: Etna, Pirâmide and Stromboli. The seeds were planted in plastic bags $(17 \mathrm{~cm}$ high $\times 9 \mathrm{~cm}$ wide) with capacity for $600 \mathrm{~g}$ of substrate, which consisted of washed sand and hillside soil, in a proportion of 1:2. The plants were grown for 30 days, until they reached a height of approximately $20 \mathrm{~cm}$ and 6-8 leaves.

Three isolates of the Colletotrichum gloeosporioides $(\mathrm{Cg})$ species were used. They were obtained from the Prof. Maria Menezes' collection (CMM), at the Universidade Federal Rural de Pernambuco, and named $\mathrm{Cg}_{1}$ (CMM_0797, papaya isolate), $\mathrm{Cg}_{2}$ (CMM_0847, guava isolate) and $\mathrm{Cg}_{3}$ (CMM_0978, mango isolate).

Conidial suspensions were prepared using 7-day-old cultures of the pathogen, grown on potatodextrose-agar in Petri dishes, to which $30 \mathrm{~mL}$ of sterile distilled water were added. The conidia were removed using a soft bristled brush, with circular movements, and the suspension was filtered through a double layer of sterile gauze. Next, conidia were counted with a Neubauer chamber, adjusting the concentration to $10^{6}$ conidia $\mathrm{mL}^{-1}$.

The 30-day-old plants were placed in a moist chamber for stomatal opening. After $24 \mathrm{~h}$, they were inoculated by spraying the conidia suspension. Capsicum plants remained in the chamber for another $48 \mathrm{~h}$, according to the methodology described by Pereira et al. (2011), adapted to local conditions.

Assessments were conducted at 3, 8, 13, 18 and 23 days after inoculation. Severity was evaluated using an adaptation of the grading scale proposed by Pereira et al. (2011): 1: plants with no symptoms; 2: $1-10 \%$ of plants with symptoms; $3: 11-25 \%$ of plants with symptoms; 4: $26-50 \%$ of plants with symptoms; 5: 51-75 \% of plants with symptoms; 6: more than $75 \%$ of plants with symptoms and/or plant death.

At the end of the experiment, the infection rate was calculated using the McKinney (1923) index and the area below the disease progression curve $(\mathrm{ABDPC})$, as it follows: $\mathrm{ABDPC}=\sum\left(\mathrm{y}_{\mathrm{i}}+\mathrm{y}_{\mathrm{i}+1}\right) / 2 \cdot \mathrm{d}_{\mathrm{ti}}$, where $y_{i}$ and $y_{i+1}$ are the severity values observed between two consecutive evaluations and $\mathrm{d}_{\mathrm{ti}}$ the interval between evaluations (Shaner \& Finney 1977). The infection rate and ABDPC were analyzed using the Shapiro-Wilk test and, on confirmation of data normality, submitted to analysis of variance, via the Tukey test ( $\mathrm{p} \leq 0.05)$, using the Assistat software, version 7.6 beta (Silva \& Azevedo 2002). Regression analysis was performed to obtain the disease progression curve, using the same statistical software. 


\section{RESULTS AND DISCUSSION}

The three Colletotrichum gloeosporioides isolates were pathogenic when inoculated in the three ornamental pepper varieties assessed. The isolates aggressiveness was influenced by the inoculation period (July/August or November/December) and the variety analyzed (Table 1$)$.

In the first assessment period (July/August), the $\mathrm{Cg}_{2}$ isolate showed the greatest aggressiveness in the Stromboli variety, differing statistically, in relation to Pirâmide and Etna (Table 1). There was no difference in the symptoms severity among the fungal isolates for each chili pepper variety, demonstrating that all three isolates may infect these three Capsicum varieties. All the positive control plants (Capsicum baccatum) died at 15 days after inoculation, demonstrating the plants vulnerability to the isolates tested. Initially, brown spots were observed on the leaves, progressing to necrosis. The seedlings also began to lean, after necrotic spots were seen on the stem. Thus, the pathogens were reisolated from the damaged tissue.

In assessments conducted during the second period (November/December), the Stromboli variety was the most susceptible to the $\mathrm{Cg}_{2}$ isolate, which differed statistically from the other isolates tested (Table 1). The Etna variety exhibited the greatest susceptibility to $\mathrm{Cg}_{1}$ and Pirâmide to $\mathrm{Cg}_{2}$ and $\mathrm{Cg}_{3}$, demonstrating the difference in sensitivity among the varieties analyzed.

The $\mathrm{Cg}_{1}$ isolate was the most aggressive to Etna, differing statistically from the other varieties. $\mathrm{Cg}_{2}$ showed no significant difference in aggressiveness among the varieties and $\mathrm{Cg}_{3}$ displayed greater aggressiveness to Pirâmide (Table 1). FreitasAstúa et al. (2005) reported that humidity and high temperatures favor the development of anthracnose in ornamental plants. These favorable conditions occurred in the Picos region during the second assessment period (November/December), due to high rainfall rates. This weather condition may explain the greater severity of symptoms observed in the pepper $\mathrm{x}$ C. gloeosporioides pathosystem studied here.

According to Soares et al. (2008), temperatures above $35{ }^{\circ} \mathrm{C}$ do not favor the development of anthracnose, since they may decrease the conidia germination and delay the disease development and symptoms emergence, regardless of relative humidity. Temperatures above $40{ }^{\circ} \mathrm{C}$ inhibit the formation of appressoria, limiting the disease development and the symptoms onset, while low temperatures may also restrict the pathogen development.

The first assessment period was characterized by high temperatures (above $35^{\circ} \mathrm{C}$ ) and low relative humidity, due to low rainfall levels. This is the most likely explanation for the differences occurred between the two assessment periods, as the high temperatures achieved in the region, from July to August, were unfavorable to the development of symptoms. Low aggressiveness may have contributed to maintain similar values of severity among isolates, in the first assessment period.

In a study with 63 chili pepper and bell pepper genotypes, four Capsicum chinense (Jacq.) genotypes were found to be resistant to Colletotrichum gloeosporioides, whereas Capsicum annum genotypes with yellow or orange fruits were more sensitive to the pathogen (Lobo Júnior et al. 2001). Sources of resistance to five isolates of Colletotrichum acutatum were investigated in seedlings and fruits of 129 varieties of chili pepper and bell pepper. The varieties analyzed ranged from extreme susceptible to resistant, and no significant correlation was observed between symptoms severity in fruits and inoculated plants (Pereira et al. 2011).

Tozze Júnior et al. (2006) studied 44 Colletotrichum isolates from nightshades, in different regions of Brazil. The authors found that the main anthracnose-causing species in this family were C. gloeosporioides and C. acutatum. Castilho \& Reis (2007) investigated the causal agent of anthracnose

Table 1. Severity of anthracnose in three varieties of ornamental pepper inoculated with Colletotrichum gloeosporioides (Cg) isolates.

\begin{tabular}{|c|c|c|c|c|c|c|}
\hline \multirow{3}{*}{ Pepper } & \multicolumn{6}{|c|}{ Colletotrichum gloeosporioides isolates } \\
\hline & $\mathrm{Cg}_{1}$ & $\mathrm{Cg}_{2}$ & $\mathrm{Cg}_{3}$ & $\mathrm{Cg}_{1}$ & $\mathrm{Cg}_{2}$ & $\mathrm{Cg}_{3}$ \\
\hline & \multicolumn{3}{|c|}{ July/August 2013} & \multicolumn{3}{|c|}{ November/December 2013} \\
\hline Stromboli & $38.88 \mathrm{aA}^{*}$ & $59.26 \mathrm{aA}$ & $38.88 \mathrm{aA}$ & $44.44 \mathrm{bB}^{*}$ & $66.66 \mathrm{aA}$ & $38.88 \mathrm{bB}$ \\
\hline Etna & $50.00 \mathrm{aA}$ & $40.74 \mathrm{bA}$ & $27.77 \mathrm{aA}$ & $62.69 \mathrm{aA}$ & $55.55 \mathrm{aB}$ & $48.15 \mathrm{bB}$ \\
\hline Pirâmide & $50.00 \mathrm{aA}$ & $33.33 \mathrm{bA}$ & $46.29 \mathrm{aA}$ & $46.29 \mathrm{bB}$ & $55.56 \mathrm{aA}$ & $66.66 \mathrm{aA}$ \\
\hline $\mathrm{CV}(\%)$ & & 25.52 & & & 21.67 & \\
\hline
\end{tabular}


Stromboli $-\mathrm{Cg}_{1}$

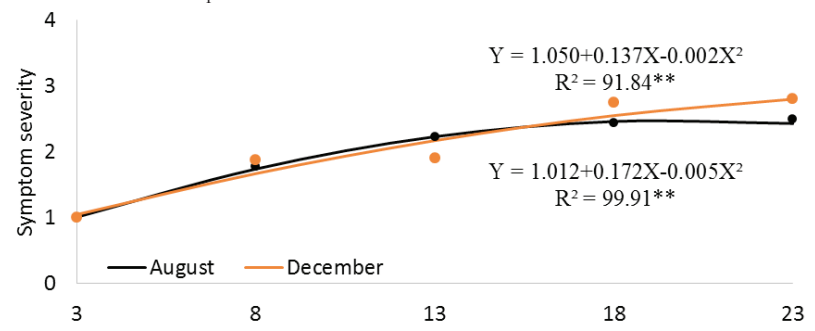

Stromboli $-\mathrm{Cg}_{2}$

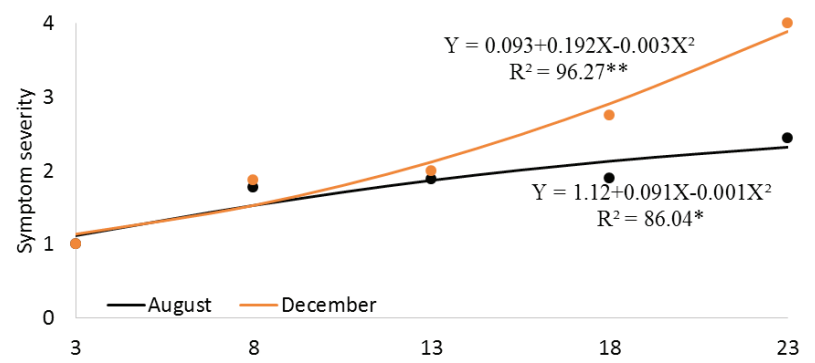

Stromboli $-\mathrm{Cg}_{3}$

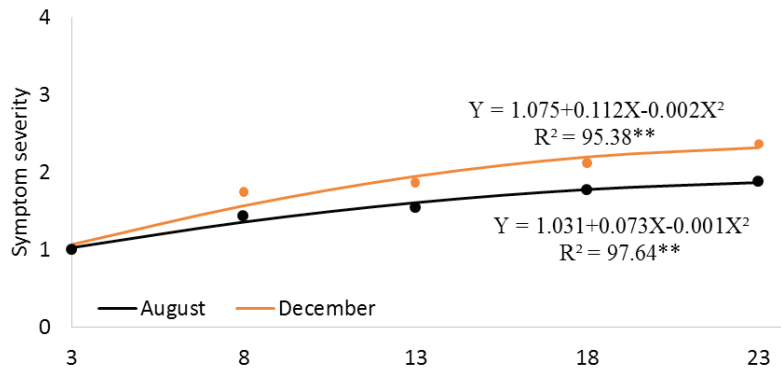

Etna $-\mathrm{Cg}_{1}$

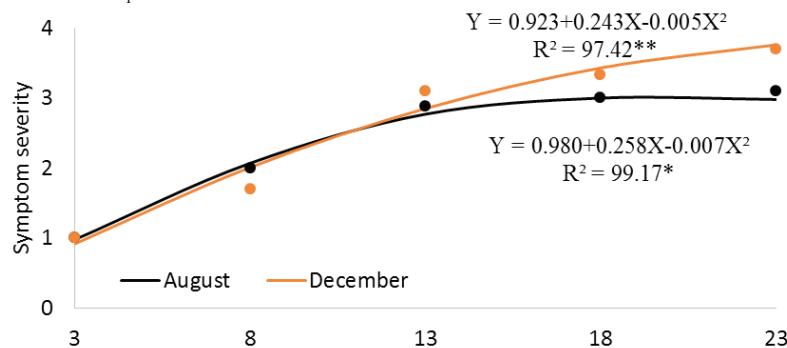

Etna $-\mathrm{Cg}_{2}$

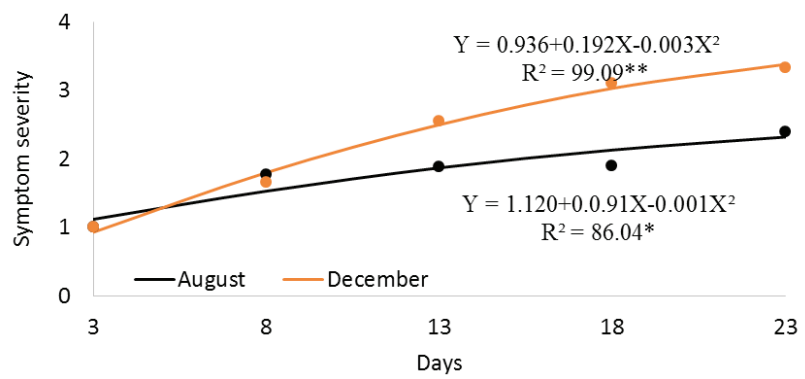

in plants from this same family and observed that C. gloeosporioides was more widespread in Brazil than $C$. acutatum, with 31 of the 46 isolates studied belonging to this species.

After regression analysis of the severity within the period of 23 days after inoculation, a pattern of anthracnose symptoms development could be observed during the two assessment periods (Figure 1).

Etna $-\mathrm{Cg}_{1}$
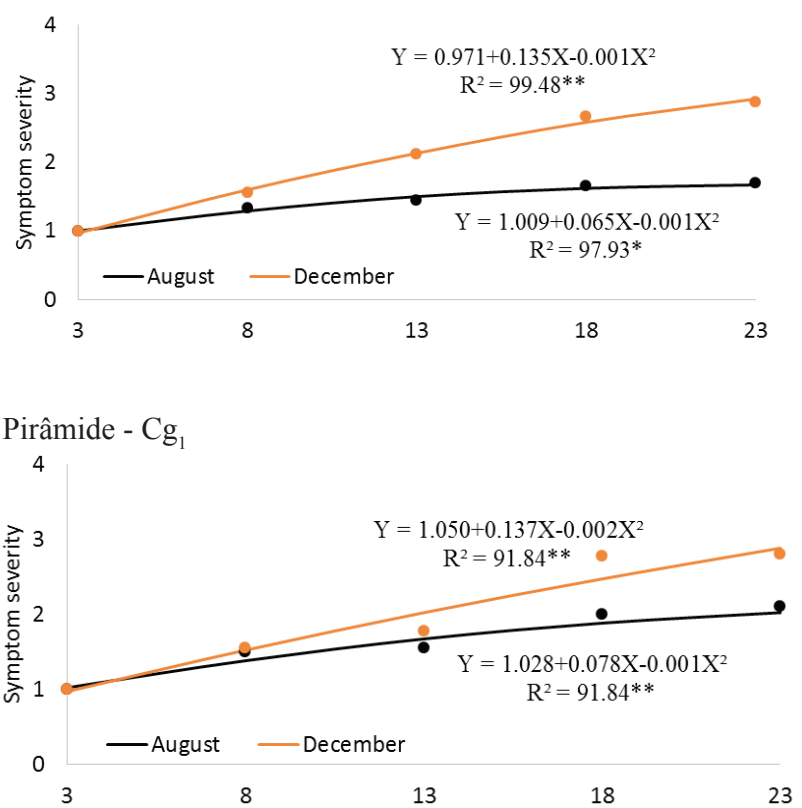

Pirâmide $-\mathrm{Cg}_{2}$
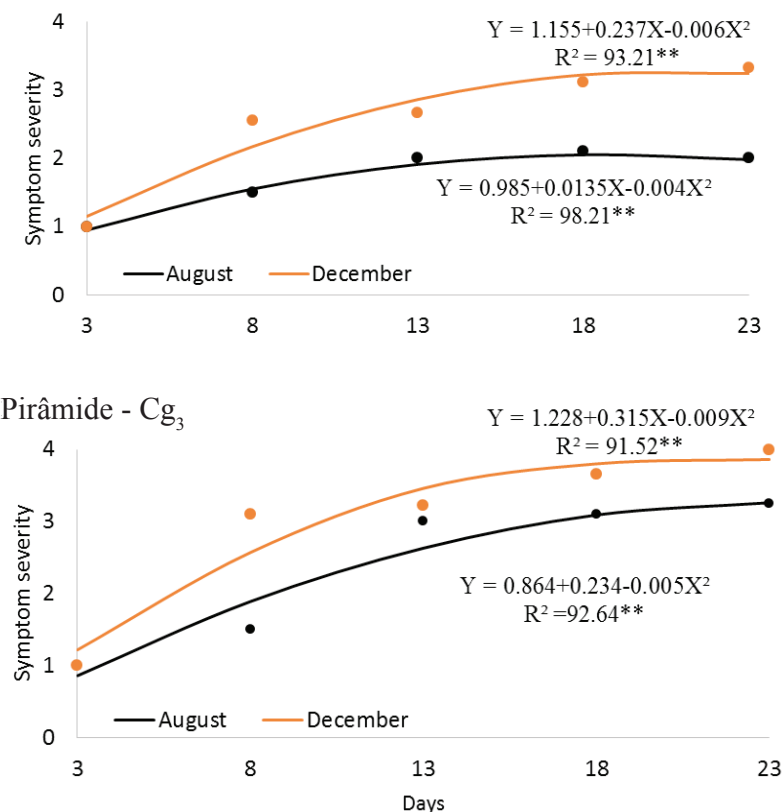

Figure 1. Development of anthracnose, caused by Colletotrichum gloeosporioides isolates $\left(\mathrm{Cg}_{1}, \mathrm{Cg}_{2}\right.$ and $\left.\mathrm{Cg}_{3}\right)$, in three varieties of ornamental pepper plants (Stromboli, Etna e Pirâmide), during two assessment periods. Model significance: $* 0.05 ; * * 0.01$. 
Symptoms severity of the isolates was greater in the second period (November/December) for all cultivars, with a significant increase in the disease development curve from the eighth day after inoculation.

Some studies on Colletotrichum spp. indicate that the temperature contributes to the colonization of tissues and symptoms onset, with the optimum temperature generally occurring between $22{ }^{\circ} \mathrm{C}$ and $28{ }^{\circ} \mathrm{C}$ (Dias et al. 2005, Poltronieri et al. 2013). These conditions were observed during the second assessment period of the experiment, favoring the disease development, which is also evident in the ABDPC assessment (Table 2). During this period, $\mathrm{Cg}_{1}$ exhibited a significant difference in symptoms severity in the Etna pepper variety. $\mathrm{Cg}_{2}$ was more aggressive in the second experiment for all the varieties studied, while $\mathrm{Cg}_{3}$ showed an increase in severity only in the Etna and Pirâmide varieties, when compared to the first assessment period.

The aggressiveness of $C$. gloeosporioides isolates was evaluated in anthuriums, torch ginger and heliconias. Although some pathogen isolates exhibited specificity in relation to the host plant, most of them were capable of infecting all three plant species tested, suggesting a lack of specificity for the isolate analyzed (Barguil et al. 2011). This also indicates the pathogen ability to colonize different hosts, which hampers control measures such as crop rotation and contributes to maintaining the pathogen inoculum in the field.

Similarly, Lima Filho et al. (2003) studied the cross-pathogenicity of Colletotrichum spp., testing C. gloeosporioides obtained from cashew apple, passion fruit, mango, papaya and C. musae (Berk \& Curt.) von Arx. isolated from banana, in these same fruits. They observed that only the passion fruit

Table 2. Area below the disease progression curve (ABDPC) for the three Colletotrichum gloeosporioides isolates inoculated in three ornamental pepper varieties, in two assessment periods (August and December 2013).

\begin{tabular}{|c|c|c|c|c|c|}
\hline \multirow{3}{*}{ Peppers } & \multicolumn{5}{|c|}{ Colletotrichum gloeosporioides isolates } \\
\hline & \multicolumn{2}{|c|}{$\mathrm{Cg}_{1}$} & \multicolumn{2}{|c|}{$\mathrm{Cg}_{2}$} & $\mathrm{Cg}_{3}$ \\
\hline & Aug & Dec & Aug & Dec & Dec \\
\hline Stromboli & $22.91 \mathrm{a}$ & $25.41 \mathrm{a}$ & $30.50 \mathrm{~b}$ & $51.64 \mathrm{a}$ & 14.57 a 19.50 a \\
\hline Etna & $17.91 \mathrm{~b}$ & $36.65 \mathrm{a}$ & $17.00 \mathrm{~b}$ & $35.82 \mathrm{a}$ & 13.32 b 29.17 a \\
\hline Pirâmide & $15.50 \mathrm{a}$ & $23.57 \mathrm{a}$ & $21.50 \mathrm{~b}$ & $39.29 \mathrm{a}$ & 14.50 b $51.24 \mathrm{a}$ \\
\hline $\mathrm{CV}(\%)$ & & & 32.84 & & \\
\hline
\end{tabular}

isolate exhibited pathogenic specificity, while the others displayed cross-pathogenicity. This explains the fact that $C$. gloeosporioides isolates obtained from different fruit species were pathogenic to the ornamental pepper plant varieties. The data obtained in this study reinforce the need to implement practices that inhibit C. gloeosporioides infestation and infection in ornamental pepper plants.

\section{CONCLUSIONS}

1. The ornamental pepper varieties Stromboli, Etna and Pirâmide are susceptible to the different Colletotrichum gloeosporioides isolates tested;

2. The isolates showed no pathogenic specificity for the varieties studied;

3. Anthracnose symptoms varied with season, indicating that environmental conditions influence the severity of this disease in ornamental pepper plants.

\section{REFERENCES}

AGRIOS, G. N. Plant pathology. San Diego: Academic Press, 2005.

BARGUIL, B. M. et al. Agressividade e produção de exoenzimas de Colletotrichum isolados de plantas ornamentais tropicais. Pesquisa Agropecuária Tropical, v. 41, n. 2, p. 200-204, 2011.

BRASIL. Instituto Nacional de Meteorologia. Dados climatológicos. 2013. Available at: <http://www.inmet. gov.br>. Access on: Dec. 26, 2013.

CASTILHO, L. B.; REIS, A. Identificação morfométrica de isolados de Colletotrichum spp. causadores de antracnose em solanáceas. Brasília, DF: Embrapa Hortaliças, 2007.

COSTA, M. H. D.; PFENNING, L. H.; POZZA, E. A. Colletotrichum coccodes: patógeno de solanáceas no Brasil. Fitopatologia Brasileira, v. 31, n. 3, p. 315, 2006.

DIAS, M. D. et al. Efeito da temperatura no crescimento micelial, produção e germinação de conídios de Colletotrichum spp. isolados de Coffea arabica. Ciência e Agrotecnologia, v. 29, n. 3, p. 545-552, 2005.

FREITAS-ASTÚA, J.; CALDARI JÚNIOR, P.; GIÓRGIA, R. Doenças das plantas ornamentais. In: KIMATI, H. et al. Manual de fitopatologia: doenças das plantas cultivadas. 3. ed. São Paulo: Agronômica Ceres, 2005. p. 523-540.

INSTITUTO BRASILEIRO DE FLORICULTURA (Ibraflor). Dados gerais do setor 12.2014: release impresa. 
2015. Available at: $<$ http://www.ibraflor.com.br $>$. Access on: Apr. 10, 2016.

LIMA FILHO, R. M.; OLIVEIRA, S. M. A.; MENEZES, M. Caracterização enzimática e patogenicidade cruzada de Colletotrichum spp. associado a doenças de pós-colheita. Fitopatologia Brasileira, v. 28, n. 6, p. 620-625, 2003.

LOBO JÚNIOR, M.; SILVA-LOBO, V. L.; LOPES, C. A. Reação de genótipos de Capsicum spp. (pimentas e pimentão) à antracnose (Colletotrichum gloeosporioides). Fitopatologia Brasileira, v. 26, supl., p. 373, 2001.

MCKINNEY, H. H. Influence of soil temperature and moisture on infection of wheat seedling by Helminthosporium sativum. Journal of Agricultural Research, v. 26, n. 5, p. 195-218, 1923.

MENEZES, M. Aspectos biológicos e taxonômicos de espécies do gênero Colletotrichum. Anais da Academia Pernambucana de Ciência Agronômica, v. 3, n. 1, p. 170-179, 2006.

NEUHAUS, M. et al. Cultivo de pimenta ornamental com diferentes densidades de planta por vaso. In: SIMPÓSIO DE ENSINO, PESQUISA E EXTENSÃO: RESPONSABILIDADE SÓCIOAMBIENTAL, 14., 2010, Santa Maria. Anais.... Santa Maria: SEPE, 2010. p. 1-6.

PEREIRA, M. J. Z. et al. Reação de acessos de Capsicum e de progênies de cruzamentos interespecíficos a isolados de Colletotrichum acutatum. Horticultura Brasileira, v. 29, n. 4, p. 569-576, 2011.

POLTRONIERI, T. P. S.; AZEVEDO, L. A. S.; SILVA, D. E. M. Efeito da temperatura no crescimento micelial, produção e germinação de conídios de Colletotrichum gloeosporioides, isolados de frutos de palmeira Juçara (Euterpe edulis Mart). Summa Phytopathologica, v. 39, n. 4, p. 281-285, 2013.
SHANER, G.; FINNEY, R. E. The effect of nitrogen fertilization on the expression of slow-mildewing resistance in knox wheat. Phytopathology, v. 67, n. 8, p. 1051-1056, 1977.

SILVA, F. A. S.; AZEVEDO, C. A. V. Versão do programa computacional Assistat para o sistema operacional Windows. Revista Brasileira de Produtos Agroindustriais, Campina Grande, v. 4, n. 1, p. 71-78, 2002.

SOARES, A. S.; LOURENÇO, S. A.; AMORIM, L. Infecção de goiabas por Colletotrichum gloeosporioides e Colletotrichum acutatum sob diferentes temperaturas e períodos de molhamento. Tropical Plant Pathology, v. 33, n. 4, p. 265-272, 2008.

STOMMEL, J. R.; BOSLAND, P. W. Ornamental pepper, Capsicum annum. In: ANDERSON, N. Flower breeding and genetics: issues, challenges and opportunities for the $21^{\text {st }}$ century. Amsterdam: Springer, 2006.

THOMAZ, L. D.; RAQUEL, R. B. N. A cadeia produtiva da floricultura no Espírito Santo.Vitória: Sebrae, 2007.

TOZZE JÚNIOR, H. J. et al. First report of Colletotrichum boninense causing anthracnose on pepper in Brazil. Plant Disease, v. 93, n. 1, p. 106, 2009.

TOZZE JÚNIOR, H. J.; MELLO, M. B. A.; MASSOLA JÚNIOR, N. S. Caracterização morfológica e fisiológica de isolados de Colletotrichum sp. causadores de antracnose em solanáceas. Summa Phytopathologica, v. 32, n. 1, p. 71-79. 2006.

XAVIER, V. C. et al. Concentração da solução nutritiva no cultivo hidropônico de pimenta ornamental. Revista da Faculdade de Zootecnia, Veterinária e Agronomia, v. 13, n. 1, p. 24-32, 2006. 